\title{
PENGARUH LUAS PERMUKAAN BONGKAHAN KAPUR API TERHADAP LAJU PENGERINGAN FILLET IKAN PATIN
}

Mursalin Mursalin ${ }^{1}$, Purwiyatno Hariyadi ${ }^{2}$, dan Soewarno T. Soekarto ${ }^{3}$

${ }^{1}$ Program Studi Teknik Pertanian Universitas Jambi, Jambi, Indonesia

${ }^{2,3}$ Departemen Ilmu dan Teknologi Pangan Institut Pertanian Bogor, Bogor, Indonesia

Email Penulis: mursalin@unja.ac.id

\section{Info Artikel}

Diterima: 10 Desember 2020

Disetujui: 12 Januari 2021

Dipublikasikan: 13 Maret 2021

\begin{abstract}
Abstrak
Penelitian ini bertujuan untuk mengetahui pengaruh ukuran bongkahan batu kapur yang digunakan pada pengeringan absorpsi terhadap laju pengeringan fillet ikan patin. Tiga macam ukuran bongkahan kapur api, yaitu $100 \mathrm{~g}$ per bongkah atau dengan luas permukaan $8.65 \mathrm{~cm} 2 / \mathrm{kg}$ (U1), $50 \mathrm{~g}$ per bongkah atau dengan luas permukaan $10.40 \mathrm{~cm} 2 / \mathrm{kg}$ (U2), dan $25 \mathrm{~g}$ per bongkah atau memiliki luas permukaan $13.09 \mathrm{~cm} 2 / \mathrm{kg}(\mathrm{U} 3)$, ditempatkan pada bagian bawah lemari pengering dan dipisahkan dengan kawat kasa dari fillet ikan patin yang ditempatkan di rak bagian atas,.perbandingan kapur: ikan (5:1). Untuk mencapai kadar air fillet ikan patin $12 \%$ basis basah, dibutuhkan waktu masing-masing selama 46,38 , dan 30 jam untuk luas permukaan bongkahan kapur $8.65,10.40$, dan $13.09 \mathrm{~cm}^{2} / \mathrm{kg}$. Pengeringan fillet ikan patin terbagi dalam 4 periode, yaitu periode transisi (kondisioning), periode cepat (pengeringan air bebas), periode lambat (pengeringan air terikat tersier) dan periode sangat lambat (pengeringan air terikat sekunder). Pada batu kapur ukuran besar, proses kondisioning dan periode pengeringan air bebas cenderung lebih cepat tetapi setelah memasuki periode pengeringan air terikat, laju pengeringannya akan sangat lambat dibandingkan dengan penggunaan ukuran bongkahan yang lebih kecil.
\end{abstract}

Kata kunci: batu kapur; pengeringan absorpsi; pengeringan lapis tipis

\begin{abstract}
:
This study aims to determine the effect of limestone size on the drying rate of catfish fillets. Three different sizes of quicklime chunks, namely $100 \mathrm{~g}$ per lump or with a surface area of $8.65 \mathrm{~cm}^{2} / \mathrm{kg}(U 1), 50 \mathrm{~g}$ per lump or with a surface area of $10.40 \mathrm{~cm}^{2} / \mathrm{kg}$ (U2), and $25 \mathrm{~g}$ per lump or having a surface area of 13.09 $\mathrm{cm}^{2} / \mathrm{kg}$ (U3), placed at the bottom of the drying cabinet and separated by wire netting from the catfish fillets, which are placed on the top shelf. The ratio of lime: fish was (5: 1). To achieve water content of catfish fillets $12 \%$ wet basis, it took 46, 38, and 30 hours respectively for the surface area of the limestone 8.65, 10.40 , and $13.09 \mathrm{~cm}^{2} / \mathrm{kg}$. Drying catfish fillets were divided into 4 periods, namely transition period (conditioning), fast period (drying free water), slow period (drying tertiary bound water), and very slow period (drying secondary bound water). In large sizes of limestone, the conditioning process and free water drying period tend to be faster but after entering the bound water drying period the drying rate would be very slow compared to the use of the smaller size of limestone lump.

Keywords: limestone; thermoreaksion, thin layer drying
\end{abstract}

\section{Pendahuluan}

Alat pengering absorbsi dengan absorben kapur api merupakan salah satu bentuk alat pengering buatan yang memiliki banyak keuntungan, diantaranya adalah dapat berlangsung pada suhu rendah, tidak menggunakan bahan bakar yang dapat menimbulkan polusi, murah dan mudah untuk dilaksana-kan dan relatif lebih cepat, bersih dan aman [1]. Kapur api merupakan bahan penyerap uap air (adsorben) yang mengandung $\mathrm{CaO}$ sebagai bahan aktif. Kapur api dengan rumus kimia $\mathrm{CaO}$, yang memiliki berat molekul 56.08 gr/mol, titik leleh $2570{ }^{\circ} \mathrm{C}$, titik didih $2850{ }^{\circ} \mathrm{C}$ dan densitas $3.40 \mathrm{~g} / \mathrm{cm}^{3}$ dengan bentuk kristal. $\mathrm{CaO}$ akan bereaksi secara 
kimia dengan uap air yang terdapat di dalam bahan yang dikeringkan sehingga kadar air bahan akan berkurang [2].

Dari hasil penelitian diketahui bahwa kapur api $(\mathrm{CaO})$ tidak mempunyai isotermi sorpsi air, karena pengikatan air oleh $\mathrm{CaO}$ bukan secara adsorpsi tetapi melalui reaksi kimia sehingga proses pengeringan dengan menggunakan kapur api disebut pengeringan kemoreaksi [3]. Kapur api sudah digunakan untuk pengeringan lada [4], brem padat [5], benih cabai [3], kultur Saccharomyces cerevisiae [6], dan jahe [7;8].

Untuk mengetahui bagaimana proses pengeringan berlangsung, perlu dilakukan analisis terhadap laju pengeringannya. Laju pengeringan dibedakan menjadi dua, yaitu laju pengeringan konstan dan laju pengeringan menurun. Laju pengeringan konstan terjadi pada lapisan air bebas yang terdapat pada permukaan bahan. Laju pengeringan ini terjadi sangat singkat, kecepatan penguapan air pada tahap ini dapat disamakan dengan kecepatan penguapan air bebas. Laju pengeringan menurun terjadi setelah periode pengeringan konstan selesai. Pada periode ini kecepatan aliran air bebas dari dalam bahan ke permukaan lebih kecil dari kecepatan pengambilan uap air maksimum [9].

Ikan patin diperdagangkan kebanyakan dalam keadaan hidup. Untuk mempertahankan mutu setelah panen, dilakukan penyimpanan beku dalam keadaan utuh atau dikeringkan. Protein merupakan komponen terbesar dalam daging ikan patin setelah air. Protein ikan terdiri atas bentuk struktural miofibrilar dan bentuk terlarut dalam cairan plasma, oleh karena itu pengeringannya merupakan proses menguapkan air yang ada dalam sarkoplasma.

Laju pengeringan fillet ikan patin terhadap waktu pengeringan dianalisis dengan menggunakan Model Matematika Pengeringan Lapis Tipis [10; 11], dalam bentuk persamaan:

$$
-\frac{d M}{d t}=k(M-M e)
$$

dimana - $\mathrm{dM} / \mathrm{dt}$ adalah laju penurunan kadar air, $\mathrm{k}$ adalah konstanta pengeringan, $\mathrm{M}$ adalah kadar air bahan dan Me adalah kadar air keseimbangan bahan. Dengan metode grafik nilai k dari persamaan (1) dapat dihitung melalui persamaan:

$$
\begin{aligned}
& \frac{M-M e}{M o-M e}=\left[e^{-k t}\right] \ldots \ldots \ldots . \\
& \text { atau } \\
& \ln \frac{M-M e}{M o-M e}=\ln A-k t
\end{aligned}
$$

Dengan mempetakan rasio kadar air terhadap waktu pada kertas semilogaritmik, maka akan didapatkan nilai $\mathrm{k}$ sama dengan kemiringan grafik. Penelitian ini bertujuan mengetahui pengaruh luas permukaan bongkahan kapur api terhadap laju pengeringan fillet ikan patin.

\section{MetodePenelitian}

Bahan utama yang digunakan adalah kapur api dan ikan patin. Peralatan utama yang digunakan adalah lemari pengering absorbsi. Alat-alat lain yang juga diperlukan antara lain adalah: oven, timbangan, desikator, thermometer, mikrometer, mistar, thermokopel dan higrometer. Lemari pengering mempunyai sejumlah rak yang dapat digunakan untuk menampung absorben kapur api maupun untuk meletakkan fillet ikan yang akan dikeringkan. Rak absorben terbuat dari bahan lembaran aluminium berbentuk wadah kotak, sedangkan rak 
untuk meletakkan fillet ikan dibuat dari bahan kassa aluminium yang juga berbentuk wadah kotak. Kapur api yang digunakan sebagai absorben adalah kapur api dengan kadar $\mathrm{CaO}$ sebesar $89.79 \%$.

Ikan patin yang digunakan dalam penelitian ini adalah yang masih segar, dibuat fillet dengan cara membuang sisik dan isi perut lalu dicuci sampai bersih baru kemudian bagian tubuh ikan disayat dengan pisau cutter menjadi bentuk fillet tipis, dengan lebar $30 \mathrm{~mm}$, panjang $70 \mathrm{~mm}$ dan tebal $2.5 \mathrm{~mm}$. Sebelum fillet ikan patin ini dikeringkan terlebih dahulu dilakukan pengukuran kadar air awal dengan metode oven.

Pada penelitian ini yang dijadikan sebagai perlakuan adalah ukuran luas permukaan bongkahan kapur api (U) yang terdiri dari 3 taraf perlakuan, yaitu U1 (berukuran besar dengan berat $\pm 100 \mathrm{~g}$ per bongkah, memiliki luas permukaan $8.65 \mathrm{~cm}^{2} / \mathrm{kg}$ ), U2 (berukuran sedang dengan berat $\pm 50 \mathrm{~g}$ per bongkah, memiliki luas permukaan $10.40 \mathrm{~cm}^{2} / \mathrm{kg}$ ) dan U3 (berukuran kecil dengan berat $\pm 25 \mathrm{~g}$ per bongkah, memiliki luas permukaan $13.09 \mathrm{~cm}^{2} / \mathrm{kg}$ ).

Percobaan dilaksanakan dengan cara kapur api berukuran sesuai perlakuan ditempatkan pada rak bagian bawah dalam lemari pengering dan fillet ikan patin dengan perbandingan berat dengan kapur api $1: 5$ disusun mendatar satu lapis pada rak pengering bagian atas. Selanjutnya untuk melihat laju pengeringan, dilakukan pengamatan terhadap perubahan berat fillet ikan dan perhitungan perubahan kadar air fillet ikan patin selama proses pengeringan.

Proses penimbangan fillet ikan dan kapur dilakukan tanpa membuka pintu lemari pengering untuk mencegah terjadinya perpindahan panas dan atau massa ke dan atau dari lemari pengering. Pada awal pengeringan penimbangan dilakukan setiap 1 jam sedangkan pada jam-jam berikutnya penimbangan dilakukan setiap 2 jam. Data hasil pengamatan yang diperoleh dari setiap taraf perlakuan ditabulasi lalu dilakukan analisa grafis.

\section{Hasil Penelitian dan Pembahasan}

\section{a) Lama Pengeringan}

Tujuan utama dari proses pengeringan adalah untuk mencapai kadar air yang aman bagi produk yang dikeringkan. Kadar air yang aman bagi produk-produk ikan tawar kering seperti fillet ikan patin adalah kadar air yang lebih rendah dari $12 \%$ basis basah [12], [13], [14]. Pada kadar air ini, produk tidak lagi dapat diserang mikroba dan lebih tahan terhadap kerusakan dan kebusukan selama penyimpanan.

Dengan menggunakan luas permukaan bongkahan kapur yang berbeda, ternyata waktu pengeringan absorbsi yang dibutuhkan untuk mencapai kadar air fillet ikan patin kurang dari $12 \%$ basis basah juga berbeda-beda, seperti dapat dilihat pada Tabel 1 .

Tabel 1. Waktu pengeringan fillet ikan patin untuk mencapai kadar air kurang dari $12 \%$ basis basah pada berbagai ukuran luas permukaan bongkahan kapur

\begin{tabular}{|l|l|l|l|l|}
\hline \multirow{2}{*}{$\begin{array}{l}\text { Luas perm. bongkahan } \\
\text { kapur }\left(\mathrm{cm}^{2} / \mathrm{kg}\right)\end{array}$} & \multicolumn{2}{|l|}{ Kadar air akhir fillet ikan $(\%)$} & \multicolumn{2}{l|}{ Waktu pengeringan } \\
\cline { 2 - 5 } & Basis Kering & Basis Basah & $($ jam $)$ & (hari) \\
\hline 8.65 & 13.220 & 11.676 & 46 & 1.917 \\
\hline 10.40 & 13.503 & 11.897 & 38 & 1.583 \\
\hline 13.09 & 13.393 & 11.811 & 30 & 1.250 \\
\hline
\end{tabular}

Ukuran bongkahan kapur berkorelasi positif dengan lama pengeringan fillet ikan patin, semakin besar ukuran bongkahan kapur semakin lama proses pengeringan berlangsung, dan sebaliknya. Untuk mencapai kadar air fillet ikan patin yang aman, waktu yang dibutuhkan berkisar antara 30 - 46 jam. Waktu pengeringan tersebut merupakan waktu yang dibutuhkan untuk proses penyeimbangan terus menerus antara kapur api yang menyerap uap air, dengan uap air yang dikeluarkan fillet ikan patin. 
Percobaan pengeringan fillet ikan yang dilakukan oleh Asikin tahun 1998 [15], memerlukan waktu pengeringan untuk mencapai kadar air di bawah $12 \%$ bb hanya 18 jam. Waktu pengeringan tersebut relatif lebih cepat dari yang dihasilkan pada penelitian ini, dan hal ini diperkirakan karena adanya perbedaan perbandingan jumlah kapur : ikan yang digunakan. Pada penelitian [15], perbandingan berat kapur dengan fillet ikan yang digunakan adalah $6000 \mathrm{~g}: 100 \mathrm{~g}$ (60:1) sedangkan pada penelitian ini perbandingannya hanya $(5: 1)$.

\section{b) Laju Pengeringan}

Penggunaan Persamaan (2) sebagai model matematika Pengeringan Lapis Tipis, didasarkan pada asumsi bahwa selama berlangsungnya proses pengeringan, $\mathrm{RH}$ dan suhu ruang pengering nilainya konstan. Bahan juga diasumsikan bersifat cukup tipis sehingga pengaruh difusi air dalam bahan yang dikeringkan dapat diabaikan.

Pada penelitian ini, suhu pengeringan relatif konstan $30 \mathrm{oC}$, RH yang berfluktuasi sepanjang waktu pengeringan. Pada awal pengeringan, RH mengalami penurunan yang cukup besar, selanjutnya terjadi peningkatan kembali pada masa kondisioning baru kemudian akan terjadi penurunan dengan laju yang tidak sama sampai akhir pengeringan. Analisis laju pengeringan absorpsi dilakukan pada data pengeringan yang terjadi setelah masa kondisioning atau setelah 4 jam proses pengeringan berlangsung, dengan asumsi bahwa RH dianggap konstan.

Analisis grafis terhadap model matematika pengeringan lapis tipis, menghasilkan kurva linier yang menerangkan hubungan antara waktu pengeringan "t" dan "-Ln $\left[\left(\mathrm{M}-\mathrm{M}_{\mathrm{e}}\right) /\left(\mathrm{M}_{\mathrm{o}}-\mathrm{M}_{\mathrm{e}}\right)\right]$ " dengan kemiringan garis (slope) yang menggambarkan nilai konstanta pengeringan " $\mathrm{k}$ " dari bahan yang dikeringkan. Semakin besar nilai k laju pengeringan bahan akan semakin tinggi. Plot data percobaan pengeringan menggunakan model matematika Pengeringan Lapis Tipis pada tiga perlakuan luas permukaan bongkahan kapur, menghasilkan kurva seperti pada Gambar 1 a, b dan c.

Kurva laju pengeringan fillet ikan patin terhadap waktu pengeringan yang diturunkan berdasarkan persamaan matematika pengeringan lapis tipis, terdiri atas empat periode laju pengeringan, dimana laju pengeringan periode 1 umumnya berlangsung lebih cepat (ditunjukkan oleh slope yang lebih curam) dari periode pengeringan berikutnya (Gambar 1). Karena perhitungan konstanta laju pengeringan (K) berdasarkan model pengeringan lapis tipis (Persamaan 2) hanya dapat dilakukan pada suhu dan kelembaban yang konstan, maka pada kurva laju pengeringan fillet ikan patin hanya dapat diturunkan dua persamaan garis lurus yang saling berpotongan pada suatu nilai lama pengeringan dan kadar air bahan yang tertentu.

Pada luas permukaan bongkahan kapur $8.65 \mathrm{~cm}^{2} / \mathrm{kg}$, perhitungan untuk penentuan periode satu dimulai dari awal pengeringan sampai jam ke-5, selanjutnya periode dua, tiga, dan empat ditetapkan masingmasing jam ke- (5-18), (18-38), dan (40-50). Untuk luas permukaan bongkahan $10.40 \mathrm{~cm}^{2} / \mathrm{kg}$, periode satu, dua, tiga, dan empat masing-masing adalah jam ke- (0-6), (6-20), (20-32), dan 34-45). Sedangkan untuk luas permukaan bongkahan kapur $13.09 \mathrm{~cm}^{2} / \mathrm{kg}$, periode satu, dua, tiga, dan empat masing-masing adalah jam ke(0-7), (7-18), (18-28), dan 32-40). Pada ketiga perlakuan, laju pengeringan periode satu mempunyai profil yang tidak bersifat linier (kurang memenuhi Persamaan (2), oleh karenanya pada periode ini tidak dilakukan analisis regresi. Hal ini disebabkan karena pola perubahan suhu dan kelembaban dalam sistem belum stabil (masa kondisioning). Melalui persamaan regresi masing-masing grafik di periode 2, 3, dan 4, dapat diperoleh data konstanta pengeringan (k) serta dapat dihitung kadar air kritikal $\left(\mathrm{M}_{\mathrm{c}}\right)$ dan waktu kritikal $\left(\mathrm{t}_{\mathrm{c}}\right)$. Nilai $\mathrm{M}_{\mathrm{c}}$ dan $t_{c}$ merupakan kadar air bahan dan waktu pengeringan pada titik potong 2 persamaan garis lurus di periode yang berdekatan. Hasil perhitungan ini selengkapnya disajikan pada Tabel 2.

Laju pengeringan periode 3 cenderung lebih kecil dari pada laju pengeringan periode 2. Hal ini diduga terkait dengan kondisi keterikatan air pada fillet ikan patin. Pada saat mencapai kadar air kritis $\left(\mathbf{M}_{\mathrm{c}}\right)$ dan waktu terjadinya peralihan $\left(t_{c}\right)$, terjadi penurunan laju pengeringan karena pada saat itu fillet ikan patin telah mulai memasuki tingkat keterikatan air yang lebih kuat. 


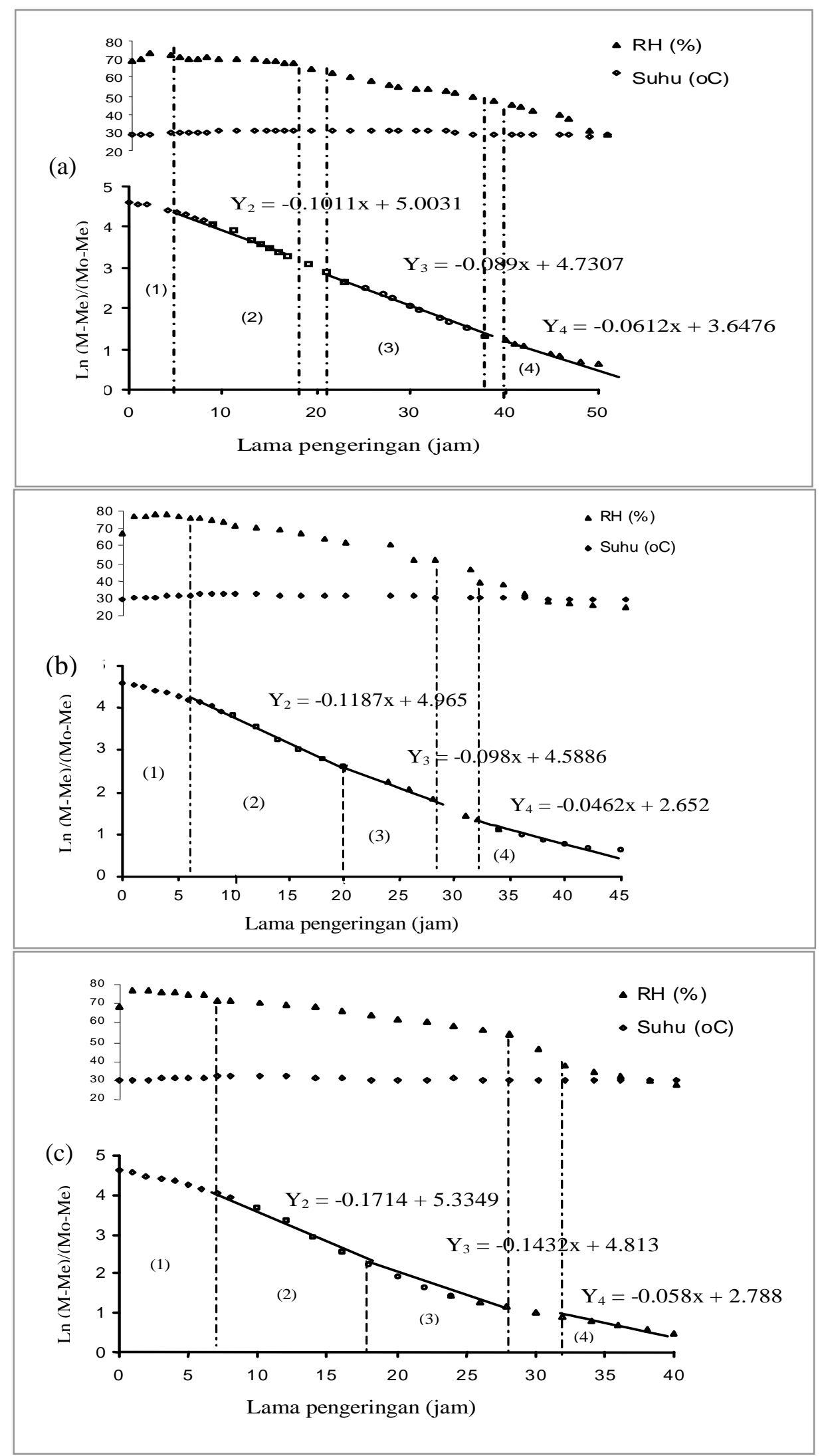

Gambar 1. Profil laju pengeringan fillet ikan patin terhadap waktu pada luas permukaan kapur $8.65 \mathrm{~cm}^{2} / \mathrm{kg}$ (a), $10.40 \mathrm{~cm}^{2} / \mathrm{kg}$ (b) dan $13.09 \mathrm{~cm}^{2} / \mathrm{kg}$ (c) 
Tabel 2. Hasil analisis laju pengeringan dengan model pengeringan lapis tipis pada pengeringan fillet ikan patin dengan berbagai ukuran luas permukaan kapur

\begin{tabular}{|c|c|c|c|c|c|c|c|c|c|}
\hline \multirow{2}{*}{$\begin{array}{l}\text { Luas } \\
\text { permukaan } \\
\text { kapur } \\
\left(\mathrm{cm}^{2} / \mathrm{kg}\right)\end{array}$} & \multicolumn{3}{|c|}{ Periode 2} & \multicolumn{3}{|c|}{ Periode 3} & \multicolumn{3}{|c|}{ Periode 4} \\
\hline & K2 & $\begin{array}{c}\text { Mc1-2 } \\
(\%)\end{array}$ & $\begin{array}{l}\text { tc } 1-2 \\
\text { (jam) }\end{array}$ & K3 & $\begin{array}{c}\mathrm{Mc} 2-3 \\
(\%)\end{array}$ & $\begin{array}{l}\text { tc2-3 } \\
\text { (jam) }\end{array}$ & K4 & $\begin{array}{c}\text { Mc3-4 } \\
(\%)\end{array}$ & $\begin{array}{l}\text { tc3-4 } \\
\text { (jam) }\end{array}$ \\
\hline \multirow{2}{*}{8.65} & -0.101 & 380.281 & 5.000 & -0.089 & 67.845 & 22.51 & -0.061 & 17.376 & 38.960 \\
\hline & \multicolumn{3}{|c|}{ Jam ke: 5-23 } & \multicolumn{3}{|c|}{ Jam ke: $23-39$} & \multicolumn{3}{|c|}{ Jam ke: $39-50$} \\
\hline \multirow{2}{*}{10.40} & -0.120 & 302.794 & 6.000 & -0.110 & 73.151 & 18.18 & -0.046 & 14.312 & 37.386 \\
\hline & \multicolumn{3}{|c|}{ Jam ke: $6-18$} & \multicolumn{3}{|c|}{ Jam ke: $18-37$} & \multicolumn{3}{|c|}{ Jam ke: $37-45$} \\
\hline \multirow{2}{*}{13.09} & -0.190 & 305.438 & 7.000 & -0.143 & 40.200 & 18.50 & -0.058 & 17.483 & 23.768 \\
\hline & \multicolumn{3}{|c|}{ Jam ke: $7-19$} & \multicolumn{3}{|c|}{ Jam ke: $19-24$} & \multicolumn{3}{|c|}{ Jam ke: $24-40$} \\
\hline
\end{tabular}

Semakin besarnya ukuran luas permukaan bongkahan kapur, semakin besar pula nilai konstanta pengeringan " $\mathrm{k}$ " yang diperoleh. Kapur dengan luas permukaan yang lebih besar memiliki potensi penyerapan air yang lebih tinggi sehingga laju pengeringannya juga lebih tinggi. Luas permukaan bongkahan kapur api yang kecil dapat memberikan efek penghambatan penyerapan air.

\section{Kesimpulan}

Luas permukaan bongkahan kapur $8.65,10.40$ dan $13.09 \mathrm{~cm}^{2} / \mathrm{kg}$ atau berat rata-rata per bongkahan masingmasing 100, 50, dan $25 \mathrm{~g}$, membutuhkan waktu pengeringan masing-masing selama 50, 45 dan 40 jam untuk mencapai kadar air fillet ikan patin di bawah $12 \%$ basis basah. Laju pengeringan fillet ikan patin terhadap waktu untuk semua perlakuan luas permukaan bongkahan kapur, mempunyai 4 periode yaitu periode transisi, periode cepat, periode lambat dan periode sangat lambat. Pada ukuran bongkahan yang besar, proses kondisioning dan periode pengeringan air bebas cenderung lebih cepat tetapi setelah memasuki periode pengeringan air terikat laju penurunan kadar air bahan akan sangat lambat dibandingkan dengan penggunaan ukuran bongkahan yang lebih kecil.

\section{DaftarPustaka}

[1] Soekarto, S.T. 2000. Pengembangan teknologi pengeringan dingin secara absorbsi dengan kapur api, untuk hasil pertanian, bahan biologi dan bioaktif. Tidak dipublikasikan. Bogor.

[2] Julianti, E. 2003. Kajian perilaku proses pengeringan kemoreaksi dengan kapur api (CaO) untuk pengeringan materi hidup (Kasus: benih cabai merah). Disertasi, tidak dipublikasikan. Sekolah Pascasarjana IPB, Bogor.

[3] Julianti, E., Soekarto, S.T., Hariyadi, P., Syarief, A.M. 2005. Pengeringan kemoreaksi untuk meningkatkan viabilitas benih cabai merah. Jurnal Ilmu Pertanian Kultura 38(2):53-62.

[4] Wulandari, N. 2002. Analisis pengeringan absorpsi dengan kapur api pada pengeringan lada. Tesis, tidak dipublikasikan. Sekolah Pascasarjana IPB, Bogor.

[5] Hersasi, L. 1996. Pembuatan brem padat dengan penambahan dekstrin dan pengeringan absorbsi. Skripsi, tidak dipublikasikan. Fakultas Teknologi Pertanian, IPB. Bogor.

[6] Novelina. 2005. Kajian pengeringan kemoreaksi dengan kalsium oksida serta dampaknya terhadap stres dan kerusakan kultur Saccharomyces Cerevisiae. Tesis, tidak dipublikasikan. Sekolah Pascasarjana IPB, Bogor

[7] Siallagan, B. 2009. Kajian proses pengeringan kemoreaksi jahe dengan kapur api (CaO). Skripsi. Fakultas Pertanian Universitas Sumatera Utara, Medan.

[8] Julianti, E., Ridwansyah, Nurminah, M. 2010. Pengeringan kemoreaksi dengan kapur api (CaO) untuk mencegah kehilangan minyak atsiri pada jahe. Jurnal Teknologi dan Industri Pangan 21(1): 51-58 
[9] Nurba, D., Wulandani, N., Purwanto, Y.A., Paramawati, R., Nelwan, L.O. 2016. Analisis sebaran kadar air jagung selama proses pengeringan dalam in-store dryer (ISD). Rona Teknik Pertanian, 9: 1124.

[10] Marinos-Kouris, D., Maroullis, Z.B. 1987. Transport Properties In the Drying of Solids. In Mujumdar, A.S. (ed.) Handbook of industrial drying. Marcel Dekker, Inc., New York.

[11] Menon, A.S., Mujumdar, A.S. 1995. Drying of Solids: Principles, Classification, and Selection of Dryers. In Mujumdar, A.S. (ed.) Handbook of industrial drying. Marcel Dekker, Inc., New York.

[12] Winarno, F.G. 2002. Pangan, gizi, teknologi dan konsumen. PT. Gramedia. Jakarta.

[13] Muchtadi, T.R. 1997. Teknologi proses pengolahan pangan. Petunjuk laboratorium. Departemen P dan K, Dirjend Pendidikan Tinggi, PAU Pangan dan Gizi, IPB.

[14] Mujumdar, A.S. 1996. Drying fundamentals. Workshop on industrial drying. Bogor, August 20-22, 1996.

[15] Asikin, A.N. 1998. Kajian model pengeringan absorbsi fillet ikan lapis tipis menggunakan $\mathrm{CaO}$ sebagai absorben. Thesis, tidak dipublikasikan. Sekolah Pascasarjana. IPB, Bogor. 